\title{
Emerging from the shadows? Perceptions, problems and potential consensus on the functional and civic roles of public affairs practice.
}

Public Relations Inquiry, 2015

\author{
Scott Davidson \\ University of Leicester \\ Oliver Rowe \\ YouGov Plc
}

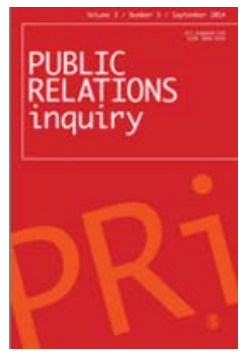

\begin{abstract}
In the context of public concern and negative media portrayals in regard to the civic impact of the public relations specialisms of public affairs and lobbying this paper seeks to expand upon normative theorising in academic PR and public affairs scholarship on practitioner roles in democracies alongside benchmarking the self-perception of sampled practitioners against those of opinion forming elites. The paper also explores how practitioners interpret their roles and locates a consensus in regard to their functional and civic contributions. $A$ potential research agenda for testing the validity of these claims of a positive civic contribution is discussed. The paper analyses the results of quantitative surveys of a representative sample of British members of parliament, and 722 UK opinion formers, plus 260 interviews with opinion-formers in Washington DC. The results were complemented by a Delphi survey of UK public affairs practitioners that sought to identify and test areas of consensus in regard to both organisational and civic functions. The research finds that lobbying is perceived as legitimate by elites but there are concerns over the quality of the information subsidy that is provided. Practitioners share an understanding with the $P R$ literature of their functional roles, and believe they make a social contribution by assisting policy-making, connecting society to politicians and as facilitators of participation and civic dialogue. This research will potentially be less applicable to the relationship between public affairs and society in other regions of the world, or in authoritarian states with low levels of interest group pluralism.
\end{abstract}

Keywords: Public Affairs, Lobbying, Research Methods, Evaluation, Democracy, Public Relations 


\section{Introduction}

Public affairs and lobbying are mainstream communication functions in organisations across all sectors of society, yet these often mundane activities attract venomous portrayals in popular culture. Media coverage draws complaints from industry bodies of unfairness as apparent scandals involve undercover journalists but no practicing lobbyists (Hawkins 2013). Regardless of the veracity of these media reports- in 2012 an OECD report concluded that " $a$ sharp and damaging ethical schism has emerged in many countries between the lobbying profession and the public" (OECD2012). This schism is indicative of a considerable gap between the self-image of practitioners and their reputation with stakeholders who are impacted upon or reliant on their activities. However, as the conclusion from the OECD report suggests, this is an issue that is far more serious than a simple image problem as it is been identified as a contributing factor in the wider decline in levels of trust in democratic politics.

The regular stream of controversies over the role of lobbying as an industry has resulted in a situation where practitioners struggle to establish their legitimacy as protagonists who make valuable contributions to societal problem solving. In the UK there have been media scandals related to: "cash for access" to senior politicians; multi-client agencies boasting to undercover reporters about their ease of access to senior government officials; elected politicians caught accepting cash to undertake advocacy work for a mythical lobby group; and concerns regarding "revolving doors" between employment in government, politics and lobbying (see Curtis 2010; Duff \& Singleton 2011; Newman \& Wright 2011; Stratton 2011; Hickman et al. 2012; Watt 2011 and the timeline of UK "scandals" provided by the pressure group Unlock Democracy http://bit.ly/1cskQ4c). In the neighbouring Republic of Ireland lobbying reform became a legislative priority in reaction to a "golden circle" of what have been perceived as inappropriately cosy relationships between politicians, bankers and property developers (McGrath 2011).

In this context it is unsurprising that studies constantly find high levels of distrust and concern within public opinion. Surveys in Sweden have found support for limiting governmental and parliamentary contact with lobbyists and concluded that consultants were seen by the public as an alien intrusion that did not belong in public life (Larsson 2007). In US surveys the public rated lobbyists as holding lower standards of ethics and honesty than car salespeople, advertisers, estate agents and telemarketers (Gallup 2011). In the UK there has been only minimal public opposition (19\%) to a law banning civil servants and military officials working for lobbying companies (YouGov/Sunday Times 2012).

The OECD has argued that the profession is now entering a period where it must understand how it can act to support democratic legitimacy. It further argues that "while lobbying continues to be a necessary and important part of democratic governance, communicating to the government the concerns of the governed, the profession in many advanced democratic societies has become so closely identified with wealthy special interests that the public's trust in government in general, and lobbyists in particular, has fallen, to dangerous lows" (2012:26). A central assumption of this paper is that socially responsible practitioners and their representatives will need to recognise this 
crossroads by pro-actively engaging with public concerns, and that this process necessitates the mainstreaming of research that enables a reflective articulation of the legitimate contribution that can be made by public affairs practice. This will require rigorous dialogue and understanding of stakeholder and public concerns. Indeed, as McGrath (2011) has argued practitioners who hope to simply evade attracting attention so that they can avoid restrictions on how they operate will only inevitably attract public disapproval of their profession, as well as the eventual imposition, for better or worse, of new regulations.

This paper seeks to capture both how PR scholars and others who situate themselves within the field of public affairs have theorised the functional and civic roles of the practice as well as explore how a sample of practitioners themselves interpret and understand their contributions. The paper also contextualises these conceptualisations through a set of quantitative surveys with elite stakeholders such as politicians and journalists. The paper reports on interviews with a representative sample of 100 British members of parliament, and with 722 UK opinion formers, which were then boosted by 260 interviews with members of political staffs in Congress and other opinion-formers in Washington DC. The results of these surveys were complemented by a Delphi survey of public affairs practitioners based in the UK. The Delphi technique involves multiple rounds of questions and is typically used to find areas of consensus amongst a specialist group of respondents. The paper concludes with a discussion on the role of research and academic scholarship in tracking public and stakeholder concerns. It will explore potential areas of consensus amongst practitioners of how to reconcile the objectives of the employer/client against wider civic needs, in the process articulating the kind of evidence base that might be required to transparently respond to both civic concerns and to test the profession's own arguments on the positive contributions it can make in restoring confidence in the integrity of democratic decision making.

\section{Theorising the place of public affairs in democratic societies}

Public affairs despite being a mainstream communications function with lobbying identified as one of the two management functions for communication professionals in Europe (Beurer-Zuellig et.al., 2009) regularly generates concern in the media and is the subject of scathing hyperreal portrayals in popular culture, of which the characters of Nick Naylor in the movie Thank You for Smoking or Remy Danton in the TV drama House of Cards would be good examples. Public concerns regarding the impact of lobbying on politics has led to international debates on the democratic contribution of public affairs practice with regular calls for new transparency regulations and registers of practitioners. This section examines the largely normative theorising within wider PR scholarship of how public affairs practitioners hold roles that support organisations in their attempts to fulfil their economic or social objectives, but also explores how the act of lobbying can be conceptualised as at least useful, and perhaps even essential in the processes of democratic decision-making.

Milbraith (1963) is frequently cited for defining lobbying as communicative acts that hold the intention of influencing governmental decision-making. The three main professional bodies in the UK likewise agreed a definition of lobbying which centred on lobbying practitioners seeking to either 
influence government at all levels, but also as advising others on how to influence government (CIPR 2013). Defining lobbying is a relatively straight forward task in comparison to public affairs which is a more complex activity that as Harris and Moss (2001) have argued is better understood as a process of managing multiple stakeholder relationships that may have policy implications. The strategic use of language and the manipulation of symbolic power has been identified as a fundamental component in public affairs practice, where practitioners compete with each other by using techniques such as framing and storytelling in attempts to establish regimes of accepted truths (Somerville 2011) and lobbying is particularly reliant on rhetorical traditions to pursue persuasive advocacy campaigns (Tusinki Berg 2012). Koeppl (2001) has portrayed lobbying groups as members of rhetorical communities and de Lange and Linders (2006) have described how practitioners associate themselves with symbols and networks of power in order to build their reputations while McGrath (2007) has endorsed the value of research that explores that use and role of language in lobbying work. Davidson has extended Harris and Moss' (2001) conceptualisation so that it incorporates the discursive dimension by defining public affairs as "the management of relationships and the building of discursive communities across a broad range of stakeholder networks in order to create, re-create, or replace shared interpretations of reality on any issue that may have policy implications." (Davidson 2014)

Some scholars have defined public affairs as an essentially corporate function. This is evidenced by Windsor's definition of the function as an interface between corporations and their non-market environments (2005) or through Hillman's (2002) insistence that firm performance should be a central concern for research in this field. There has also been a tradition within business-oriented scholarship to locate issues management as a key process in corporate public affairs practice. Issues management emerged in the 1970 s as a corporate response to the rise of identity politics, civic and environmental movements. These social movements gained policy influence via their adoption of innovative advocacy campaigning (Heath 1997). Processes were centred on the ability to identify emerging issues and formulate responses that sought to ensure issues did not turn into reputational or political crises. The perceived inadequacy of corporate counter publicity strategies presented the impetus to develop issues management processes often with the objective of resisting new social and environmental regulations (Heath 1997), in turn this prompted the trend for public affairs practitioners to increasingly incorporate forecasting and futures research into their strategic planning (Renfro 1993). More recently scholars have advocated elements of social responsibility should be included in the definitions. McGrath et al. (2010) have argued the value of public affairs could be best realised when it is able to perform the role of ethical balance against the profit-motive as the sole driver of corporate decision-making. Likewise a civic value can be found in attempts to align organisational values with the public's interests (Fleisher 2012) and Boddewyn (2012) encourages practitioners to pro-actively identify social concerns and apply internal pressure on employers or clients to find ways of contributing to their solution. This trend of incorporating the interests of wider society into discussions on the purposes of public affairs practice mirrors the longer tradition of adding normative aspirations when defining the wider field of public relations. There have been attempts to define public relations as a process that seeks to create either mutually beneficial or mutually influential relationships (Grunig et al. 2002, Coombs and Holladay 2007), while scholars such as Heath (2001) have consistently emphasised the rhetorical dimension to 
organisations adapting to the interests of external audiences and attempting to co-create meaning. In Britain, the Institute of Public Relations' code stated in 1963 that members shall conduct "professional activities with respect for the public interest" (L'Etang, 2004:171).

While the positing of mutual understanding suggests a more ethically grounded orientation, it tends to encourage a focus on what can be a diffuse set of bilateral relationships. A more aggregative approach is potentially offered by the application of social capital theories. The social capital framework draws upon Putnam (1995) to argue that strategic relationship building activities such as public affairs and advocacy, and the manner in which discursive spaces are created, can be seen to be contributing to democracy as the actions of groups increase the probability of future acts of cooperation between groups taking place and in turn intensify levels of engagement from citizens (Taylor 2009, Yang and Taylor, 2013). The argument here is that the normative role for public affairs practitioners in a democracy is seen through how they can create social capital when they facilitate access to spheres of public discussion, for the organisations they represent, but also for the individual citizens who participate in these events and processes. As Sommerfeldt (2013) demonstrates, the value of social capital can be illustrated when contemplating the consequences of low levels of trust, as this entails increasing intolerance toward different opinions with centralised authorities taking over the responsibility for problem solving, but in the process becoming averse or even hostile to public dialogue. Trust is a key concept when applying social capital frameworks to research as trust between individuals, and between individuals and institutions, facilitates ongoing interaction and wider cohesion (Luoma-aho 2009). Public affairs practitioners, based on either longterm or contingent shared interests, will seek to build stakeholder relationships and rhetorical communities. On occasions the strategy of building coalitions and alliances between groups of citizens, will sponsor networks of interaction outside of their more usual homogenous social networks, in the process, it is argued, creating trust and tolerance of diverse socio-cultural perspectives (Sommerfeldt 2013).

These debates regarding the democratic utility of the creation of networks or public spaces in order to advocate policy issues featured strongly during the progress of lobbying legislation in the UK in 2013. Defended as legislative action that would rebuild trust in politics, the Conservative-Liberal Democrat coalition included proposals in the Transparency in Lobbying, Non-Party campaigning and Trade Union Administration Bill that would put in place what many professional and voluntary sector organisations argued were effective legal restrictions on their ability to influence public policy in the 12 months before any national election. In a coordinated response over 50 charities, campaign and community groups formed the Commission on Civil Society and Democratic Engagement (CCSDE). In its final report (CCSDE 2013) the commission forcefully argued that issue focused campaigns were essential for a "healthy" democracy, noting that independent groups are core to civil society, and in turn many groups are founded on principles that compel them to seek to influence politicians and law making. The commission argued that local campaigns or social action projects were one of the most common forms of civic participation. Many groups felt the measures would be to the benefit of political elites, as the ability of community groups to use their campaigning creativity to influence media agendas would be taken away from them in election years. When faced with what appeared to be the prospect of significant restrictions on the advocacy functions of public affairs practice, 
groups used a social capital defence of the importance of these activities, as well as arguing the their value in terms of acting as check and balances on executive or elite power.

When focusing on the processes of governmental administration or legislative procedures the concept of the information subsidy can be usefully applied. Here public affairs provides information resources such as briefings or research reports for civil servants and legislators. Decision makers rely on information on present or future conditions in order to evaluate policy options. Public affairs practitioners can assist the quality of this process through the supply of research, opinion and analysis, but in this process there will also be opportunities to exert some kind of competitive advantage (Gandy 1992). The information subsidy is a well-established concept (Turk 1985, Zoch and Molleda 2006) for understanding how public relations practitioners reduce the costs of news gathering through the provision of information, story ideas, visual events and the availability or spokespeople for interview or the identification of ordinary citizens who may have been affected by a particular issue. In a similar vein the information subsidy provided in public affairs contexts reduces the financial and time costs for officials and legislators in accessing and analysing information that is required in order to execute their functions. The subsidy provided would include information on attitudes and dispositions of stakeholders in any given policy arena, but also a flow of expertise and future oriented technical commentary on the likely impacts of legislative options. In the same way that the information subsidy for journalists needs to chime with their conceptions of newsworthiness, the subsidy for legislators needs to be translated into demonstrating how it supports the needs of administration and practical problem solving. Bouwen (2002) has been influential in applying these models to the study of the relationships between EU policy-makers and interest groups, particularly in the way business groups can gain access through the provision of expert knowledge which is in demand from officials and legislators, in turn this access provides the potential, although does not guarantee, for influence on agendas. Hall and Deardorff extend this concept further by arguing that lobbying is "primarily a form of legislative subsidy - a matching grant of costly policy information, political intelligence, and labor, to the enterprises of strategically selected legislators" (2006:69). This process can be illustrated by the practice of groups who lobby on health policy who routinely attempt to translate clinical research and knowledge into tangible policy gains such as the economic benefits gained for businesses through lowering sickness absence rates or by reducing public administration costs through the prevention of future admissions, or readmissions, into hospital care. More widely this flow of information can be argued as improving democratic performance as lobbyists rigorously and critically test the potential implications of new policies and in the process creating moments of engagement between politicians and civic groups or the citizens they have mobilised.

The utilities of rhetorical exchange, social capital, the information subsidy, and the ability of groups to provide checks and balances on executive power all represent promising, if predominantly normative, frameworks for research, but with the permanent recognition that public affairs practice does not take place on neutral terrain. Possessing the most logical arguments or a sincere motivation to improve economic productivity or redress social injustices does not automatically translate into influence. Public affairs practice will always take place in the context of the structural power relationships within any society, and the dynamics of these relationships should be expected 
to manifest themselves in processes and outcomes. This political economy paradigm has been used to develop arguments that suggest that elite groups, and particularly large corporations, are able to use their superior resources to dominate public debate and decision-making environments (Dinan and Miller 2007). Studies suggest these vested interests appear to have been able to frustrate public health initiatives in areas such as obesity and alcohol pricing (Miller and Harkins 2010, Gornall 2014) or how the entertainment industry has coordinated influence on copyright laws across a range of institutions in a manner which Horten (2013) argues has been the expense of internet freedoms. Schlozman et al's. (2012) quantitative examination of the range and nature of organised groups seeking to influence policy concluded there was a dearth of groups who sought to represent disadvantaged citizens or the general public, which may help to explain why Kimball at al. (2012) found only weak correlations between lobbying agendas and the priorities of the public or Gilens \& Page's (2014) matching up of expressed policy preferences in polling and policy outcomes which led them to conclude that median income citizens have little or no independent impact upon public policy in the US.

While economically powerful interests are able to use public affairs and lobbying to translate their material advantages into policy influence, studies suggest that the level of this advantage is uncertain and may even only be quite weak. Baumgartner et al. (2009) could not find any evidence of a correlation between lobbying resources and policy change. Likewise Smith (2000) concluded that business interests were less influential on public policy than either public opinion or electoral outcomes. From interviews with lobbyists Parvin (2007) found that practitioners working for corporations complained they had to "struggle" against a bias from UK legislators toward charities and against business. . These inconsistent findings across many of these published studies suggest that it should not be assumed that groups with more resources automatically enjoy higher levels of influence, but equally the existence of rigorous competition between groups will not necessarily equate to policy outcomes that are either fair or logical (Godwin et al. 2012).

The next section explains the methodology for this paper and how it has used surveys and the Delphi method to generate new data on how lobbying is viewed by opinion-formers and on the selfperceptions of public affairs practitioners in regard to their contributions to both their employer/client and to society more generally.

\section{Methodology}

This paper was able to utilise the international opinion research company YouGov's regular panel of opinion formers to conduct a structured survey with a representative sample of 100 British members of parliament, and with 722 UK opinion formers of whom 140 were journalists. This structured survey was supplemented by 260 interviews with Congressional staff members and other American opinion-formers in Washington DC. The results of these surveys were additionally complemented by a Delphi survey of public affairs practitioners based in the UK. The aim of the Delphi was to establish areas of consensus amongst practitioners in regard to their functions in support of their client/employer as well as their contribution to society more widely. This was an interpretive 
approach, where the sample from this community of practice defined itself in its own terms. This allowed this paper to then to explore how theory and research might be applied to test the real world veracity of these claims. The surveys of opinion formers in London and Washington, in addition to providing benchmarks of the reputation of lobbyists with elite stakeholders, enabled contextualisation of their responses to the Delphi survey.

\section{Structured surveys of elected politicians and other elite opinion formers}

In the structured surveys results for MPs were weighted by party, gender, electoral cohort, and geography to give a sample that is representative of the House of Commons. No weighting is applied to the opinion formers or journalists who are not designed as representative samples. As all results were based on a sample and are therefore subject to statistical errors normally associated with sample-based information. For this survey, based on a $95 \%$ confidence level results for the full sample of MPs are correct to plus or minus 9\%. Due to rounding up or down of results, not all percentages may add up to and likewise percentages which are added together may seem to add up to more or less than their constituent parts.

YouGov maintains a panel of journalists and general opinion formers in the UK who take part in regular online research surveys. This panel consists of individuals drawn from a wide variety of backgrounds including business, third sector, academia, media, arts, and politics. All members of this panel were invited to take the online survey and 722 individuals from the panel completed it. 140 of those who completed it were journalists, working primarily across broadcast and printed media, rather than digital-only. Online surveys were completed with 260 Washington-based, politically active respondents. Of these 70 were staff in Congressional offices (predominantly in the House of Representatives) and 190 were more general political 'insiders', made up of consultants, strategists, lobbyists and pollsters. The questionnaire was refined for this group to ensure its relevance in the US but the essence of each question remained the same. The London and Washington samples varied in terms of roles within the processes of each of the two differing legislative systems, but common to both samples is that the respondents are closely involved in conducting, receiving or reporting on lobbying.

The first question asked respondents to state the extent to which they agreed or disagreed with eight statements about lobbying. Topics ranged from fundamental beliefs about the legitimacy of lobbying through to the professional standards of practitioners.

\section{The Delphi Method}

The Delphi method is typically centred on generating ideas and facilitating the discovery of areas of consensus from a group of participants who share specialised knowledge or insight. The process for a Delphi study frequently commences with semi-structured surveys and open-ended questions which are then analysed by the researchers. Additional surveys are then circulated to test for levels 
of agreement with the analysis of the first survey. As the process develops a Delphi study will move towards demonstrating areas of consensus, or on occasions it may become clear there is no strong consensus amongst participants (Verčič et al. 2001). As Kennedy (2004) notes an advantage of a Delphi study is how samples of experts are enabled to communicate their opinions anonymously and to see how their initial responses compare with others from that same community of expertise. Additionally, unlike other methods that involve group interactions, the Delphi method is relatively safe from the problem of the process being skewed by one or two individuals dominating the exchanges (Watson and Wakefield 2014). To date there have not been any Delphi studies that have drawn on public affairs practitioners as its sample point or explored issues in relation to lobbying practice. There had been one attempt by White and Blamphin (2002) to help establish research priorities for the European Centre of Public Affairs, but as Watson and Wakefield (2014) note this initiative only drew a limited number of responses and versions of publication itself are no longer easily located.

The Delphi study completed for this paper was a two-step process that began by inviting potential respondents to complete the first survey online. All 946 individuals on the UK Public Relations Consultants Association (PRCA) membership database were invited to take part in the project. More than one individual from any given organisation could complete the first stage.

The first wave of the study was completed by 99 individuals. 79 came from multi-client agency professionals, 17 were in-house professionals, and three were freelance professionals. Respondents were of mixed levels of experience with the mean number of years spent in the industry being 7.1. 63 respondents were male and 36 female. Respondents' job titles ranged from business owners to basic executive level. A gap of around 10 days occurred between closing the first wave of the Delphi survey and then sending email invitations asking individuals to take part in Wave two. The invitation to the second wave was sent to all those on the original database, except for 30 individuals who, courtesy of automated replies, were found to have left their company. Participation in the second wave was not limited to only those who had completed Wave one as no questions in Wave two were dependent on previous participation and Wave two consisted primarily of trying to reach a consensus using the breadth of findings from Wave one. 40 individuals completed Wave two of the Delphi process. 28 individuals completed both Waves one and two. The sample size compared well with previous Delphi studies and Watson and Wakefield's (2014) methodological literature review which suggested minimum sample sizes were adjudged to range somewhere between 10 and 30 participants.

The first round of the study was designed to draw a wide breadth of spontaneous views. The focus was on trying to gather an understanding of what practitioners see as the positive contributions they make to their clients and also how, and if, the industry makes a positive contribution to society as a whole. Participants also responded to the same list of statements that were shown to politicians, journalists and general opinion formers, and provided their level of agreement on the same five point scale. Finally the questionnaire asked respondents to write in "any methods or metrics you believe should be used to help evaluate the main contributions of public affairs and lobbying to wider society". 


\section{Results of the structured surveys}

UK Results

Perhaps the most important question of the survey asked about the legitimacy of the lobbying process. It is therefore encouraging for the public affairs industry to find that all three major groups agree with the statement: "lobbying is an important part of the democratic process". Agreement (Table I.) is highest among MPs, with $75 \%$ stating they agree or strongly agree, compared to $67 \%$ of general opinion formers, and $56 \%$ of journalists. However it should be noted that agreement for each group is mainly focused around the response that they 'tend to agree' rather than 'strongly agree'. For MPs there is also no significant difference between Conservative and Labour MPs.

There was also some support for the statement "all organisations should have the right to lobby Members of Parliament". Again it is MPs who are the most likely to agree with this statement, as $86 \%$ of those surveyed tend to agree or strongly agree with it. Opinion formers are only slightly behind MPs, with $80 \%$ of them agreeing, while journalists again show the weakest level of endorsement of the three groups surveyed, with $70 \%$ agreeing. All three groups certainly show more support for this statement than the more general one about lobbying being an important part of the political process. However interpretation of this statement should be approached with a certain amount of caution. What respondents are possibly saying is that if one organisation has a right to lobby then so should all but this is regardless of whether they actually support the process of lobbying or not.

Perhaps the statement that indicates a contributing factor toward the industry's reputational problems is the low levels of agreement that "the lobbying process in the UK is generally transparent". Only $22 \%$ of MPs agree with this, while the scores fall further for opinion formers at $13 \%$ and just $7 \%$ of journalists. This limited belief that lobbying is generally transparent is further borne out in the statements asking about standards. Very low proportions of journalists (14\%) and opinion formers (22\%) would agree that "most lobbyists adhere to professional standards", but in contrast a majority of MPs (51\%) do agree with this.

Table I: Responses to lobbying survey. Base: 722 UK opinion formers, Nov $22^{\text {nd }}-28^{\text {th }} 2012$ (incl. 140 journalists) 100 UK MPs representative of the House, Nov 27 $7^{\text {th }}-$ Dec $10^{\text {th }} 2012$ 
All organisations should have the right to lobby Members of Parliament

Lobbying is an important part of the democratic process

I support the formation of a compulsory register of all lobbyists

Most lobbyists adhere to professional standards

In general I find lobbyists provide information which is true and accurate In general the professional standards of lobbyists are improving

The professional codes and standards of lobbying are rigorous enough

The lobbying process in the UK is generally transparent

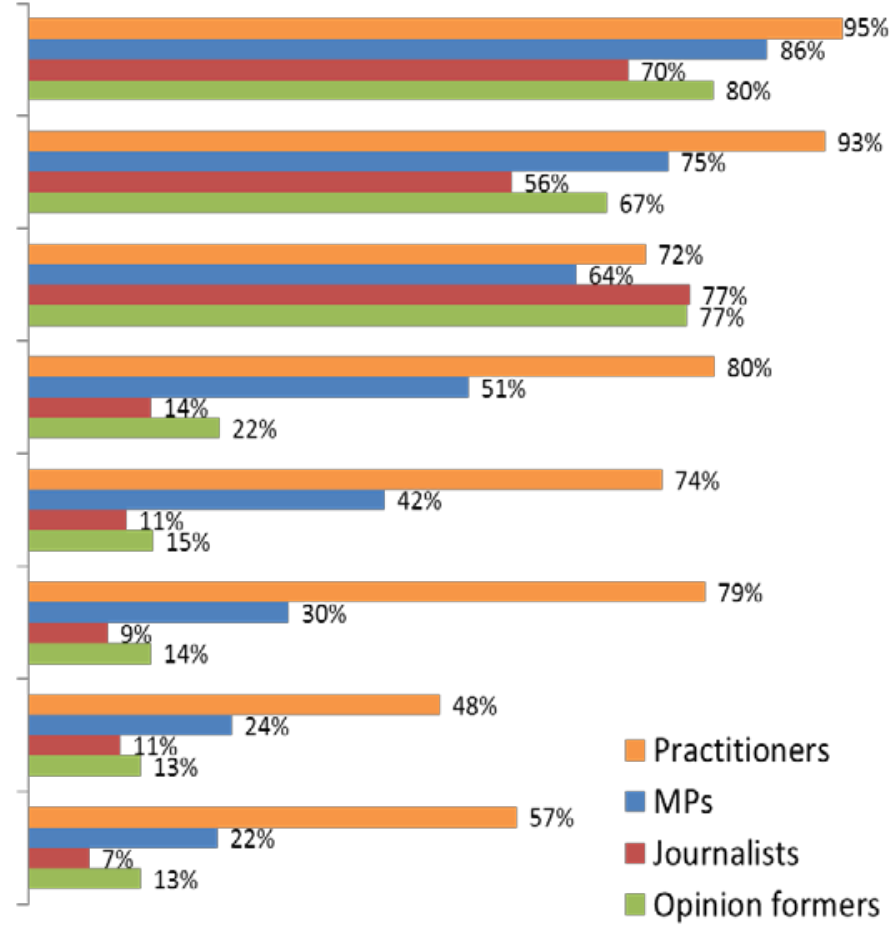

While sampled MPs (Table II.) generally agreed that lobbyists do adhere to professional standards they did not agree that "the professional codes and standards of lobbying are rigorous enough". There is also limited evidence that standards are improving. 30\% of MPs agreed that "in general the professional standards of lobbyists are improving" but yet again agreement is much lower for journalists (9\%) and opinion formers (14\%). Perhaps most disappointing for practitioners and their potential to provide a valued information subsidy, is the low level of agreement to the statement "in general I find lobbyists provide information which is true and accurate". The MPs were not in outright disagreement with this statement but only $41 \%$ actually agree while $8 \%$ disagreed and $50 \%$ neither agreed nor disagreed. Agreement from Journalists (11\%) and opinion formers $(15 \%)$ is again noticeably low.

Taken together these statements paint a poor picture for the profession. While the legitimacy of what is done gets general support, the quality of the contributions of public affairs practitioners was not strongly endorsed by the sampled journalists and general opinion formers. With MPs the results are more positive though there is a clear split along party lines.

Table II: Base: 100 UK MPs surveyed November 27 to December 10, 2012. 


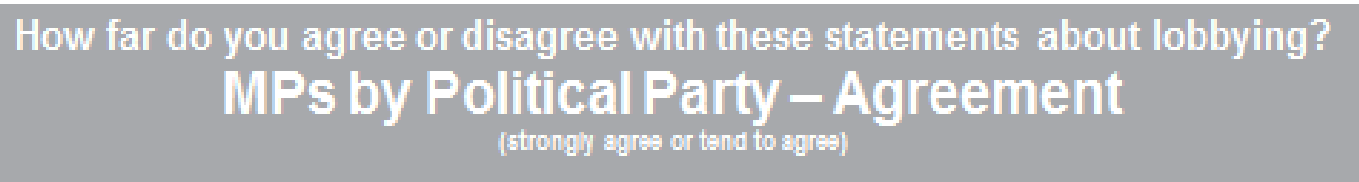

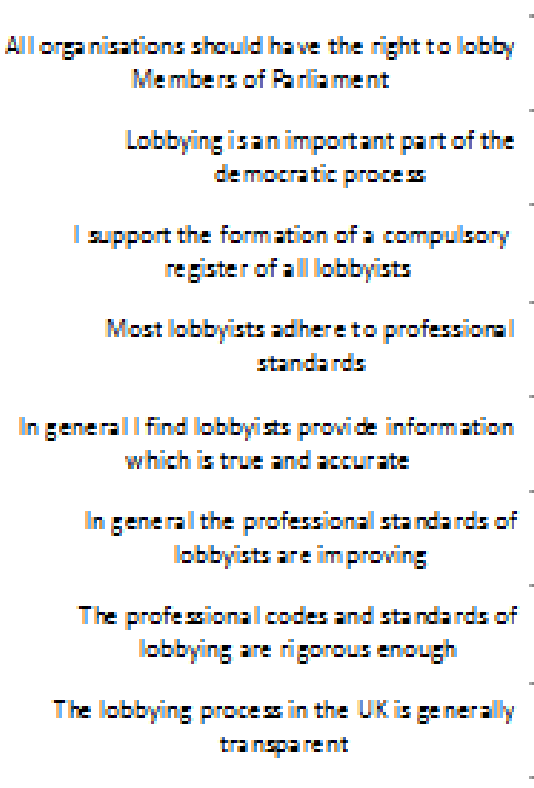

Bss: 100 UK. MPs, November 27 th - Desember 10 th 2012

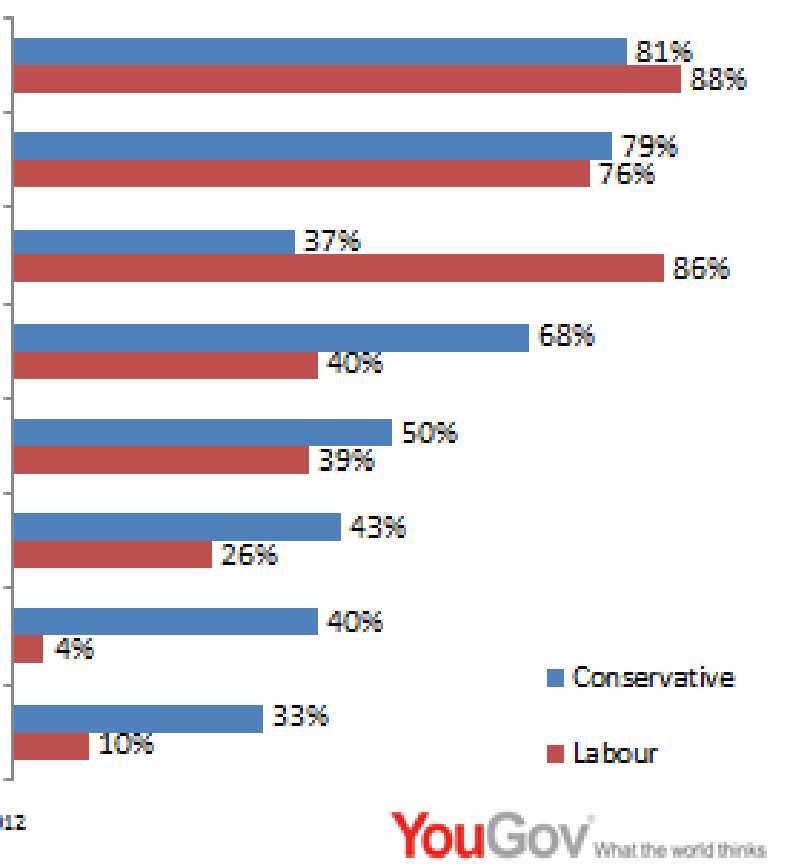

\section{Washington DC Results}

Looking at the findings for the sample in Washington DC, it was found again that the legitimacy of lobbying receives strong support with $86 \%$ agreeing (either 'strongly agree' or 'somewhat agree') "all organisations should have the right to lobby Members of Congress". Agreement slips slightly to $80 \%$ among Congressional staff compared to $94 \%$ for the political insiders, many of whom are themselves lobbyists, and for whom $76 \%$ 'strongly agree' compared with $50 \%$ of Congressional staff. It is also no surprise to also find that agreement is very high with the statement "lobbying is an important part of the democratic process" with $81 \%$ of Congressional staff agreeing, as well as $86 \%$ of political insiders. When it comes to the question of transparency, almost half (49\%) of the Congressional staff agree "the lobbying process in the US is generally transparent" while almost a third (31\%) actively disagree. Agreement is lower with the political insiders of whom $36 \%$ agree while $46 \%$ actually disagree, of whom $18 \%$ disagree strongly.

In the UK (Table II) 51\% of MPs agree that "most lobbyists adhere to professional standards" but in Washington $70 \%$ of Congressional staffers state agreement but this slips to $63 \%$ of the political insiders. Almost two thirds (63\%) of the Congressional staffers also believe that "the professional codes and standards of lobbying are rigorous enough" but again agreement from political insiders is lower at just $42 \%$ while $31 \%$ actually disagree. $69 \%$ of staffers and $48 \%$ of insiders think "professional standards of lobbyists are improving" which far outstrips the $30 \%$ of UK MPs who agree. A similar percentage of staffers (64\%) also agree that "in general I find lobbyists provide information which is true and accurate", and $60 \%$ of insiders also agree, compared to $41 \%$ of UK MPs who also agree. 
Respondents were also asked about the registration of lobbyists and $48 \%$ of all those interviewed feel that "regulation of lobbyist registration should be more strongly enforced", with $44 \%$ of Congressional staff and $49 \%$ of political insiders agreeing.

The results from Washington seem to be relatively more positive towards practitioners than the UK equivalents. Support for lobbying as a right, and as part of the democratic process, is extremely high with the U.S. audiences, which mirrors the UK MPs' findings, but agreement with the view that practitioners are professional and provide accurate information is higher in the US. There is no doubt that the way lobbying, and the political affiliation of many lobbyists, works in Washington is very different to the UK and this relationship may lead to some of the higher scores, but it is still interesting to note that the rigour of professional codes and levels of transparency in particular have room for improvement in both groups' view, even if the U.S. starting point is higher.

Table III: Base 260 Washington-based, politically active respondents

\begin{tabular}{|l|cc|cc|cc|}
\hline $\begin{array}{l}\text { \% AGREE (strongly or somewhat) } \\
\% \text { DISAGREE (strongly or somewhat) }\end{array}$ & \multicolumn{2}{|c|}{$\begin{array}{c}\text { All Washington } \\
\text { Elites }(n=260)\end{array}$} & $\begin{array}{c}\text { Congressional } \\
\text { staffers ( } n=70)\end{array}$ & \multicolumn{2}{|c|}{$\begin{array}{c}\text { Political Insiders } \\
(n=190)\end{array}$} \\
\hline & Agree Disagree & Agree Disagree & Agree Disagree \\
\hline $\begin{array}{l}\text { All organisations should have the right } \\
\text { to lobby Members of Congress }\end{array}$ & $90 \%$ & $5 \%$ & $80 \%$ & $9 \%$ & $94 \%$ & $3 \%$ \\
\hline $\begin{array}{l}\text { Lobbying is an important part of the } \\
\text { democratic process }\end{array}$ & $85 \%$ & $6 \%$ & $81 \%$ & $7 \%$ & $86 \%$ & $6 \%$ \\
\hline $\begin{array}{l}\text { Most lobbyists adhere to professional } \\
\text { standards }\end{array}$ & $65 \%$ & $15 \%$ & $70 \%$ & $14 \%$ & $63 \%$ & $15 \%$ \\
\hline $\begin{array}{l}\text { In general I find lobbyists provide } \\
\text { information which is true and accurate }\end{array}$ & $61 \%$ & $16 \%$ & $64 \%$ & $11 \%$ & $60 \%$ & $18 \%$ \\
\hline $\begin{array}{l}\text { In general the professional standards of } \\
\text { lobbyists are improving }\end{array}$ & $53 \%$ & $18 \%$ & $69 \%$ & $11 \%$ & $48 \%$ & $20 \%$ \\
\hline $\begin{array}{l}\text { Regulation of lobbyist registration } \\
\text { should be more strongly enforced }\end{array}$ & $48 \%$ & $24 \%$ & $44 \%$ & $27 \%$ & $49 \%$ & $23 \%$ \\
\hline $\begin{array}{l}\text { The professional codes and standards } \\
\text { of lobbying are rigorous enough }\end{array}$ & $48 \%$ & $28 \%$ & $63 \%$ & $20 \%$ & $42 \%$ & $31 \%$ \\
\hline $\begin{array}{l}\text { The lobbying process in the U.S. is } \\
\text { generally transparent }\end{array}$ & $40 \%$ & $42 \%$ & $49 \%$ & $31 \%$ & $36 \%$ & $46 \%$ \\
\hline
\end{tabular}

\section{Results of the Delphi Study}

The contribution of public affairs and lobbying practitioners to their employer or client

From the 99 responses to the first wave of the Delphi study, the thematic analysis identified nine clusters. These themes were then tested in the second wave to assess the strength of agreement amongst practitioners. Table IV. displays the percentage of respondents in the second wave who agreed with each theme as constituting a positive contribution to employer or client, and how many agreed that that the contribution should be talked about publicly. 
There was a near unanimous agreement (95\%) that practitioners positively contribute to their employer by drawing upon and utilising their specialised knowledge of governmental and parliamentary agendas. Knowledge of the workings of these institutions is supplemented by wider intelligence and monitoring of the external political, business or social environments that may become significant for the employer/clients. The second theme which generated near unanimous agreement levels (95\%) relates to the operationalising of this specialised knowledge and intelligence to enable employer/clients to influence specific legislative proposals and public policy agendas more widely. There was also a strong consensus (83\%) that this knowledge enables practitioners to advise on senior management functions such as the development of organisational strategies.

Although the highest level of consensus accumulated around knowledge transferring into influence of legislation and public debate, another area of significant consensus supported the view that public affairs practice is not solely focused around communications and relationships with elected representatives or their civil servants. The concept and theory of stakeholders was an important theme, with practitioners showing a strong consensus (90\%) that understanding and managing relationships with stakeholders was a key function in their contribution to their employer/clients. Another area of strong consensus suggests agreement amongst practitioners that a contributory variable that will assist in building relationships and influences is that of reputation. Strong levels of consensus were found (90\%) with the statement that public affairs practitioners contribute to their employer/clients by assisting them in raising their media and political profiles. This activation of specialist knowledge in order to enact legislative influence, raise public profiles and nurture stakeholder relationships was agreed $(75 \%)$ by practitioners as positively contributing to organisational "bottom lines", that is to say that success is frequently oriented around assisting employer/clients in achieving organisational goals.

Finally, there were two themes that appeared in both the Delphi questions on contribution to employer/clients and on contribution to wider society. These will be discussed in the next section.

\section{Table IV: Responses to question:}

Please consider each of the options below in turn. First, please say whether each is something you recognise as being a main positive contribution of public affairs and lobbying to your employer (if you work in-house) or clients (if you work in an agency) and tick the box if it is. Then, please indicate whether you believe it would benefit the public affairs industry as a whole to talk more publicly about this contribution (assuming it could be proven). If you don't believe either point applies then select 'Neither'.

Base: Wave1 99 practitioners, Wave 240 PA practitioners, March 2013 


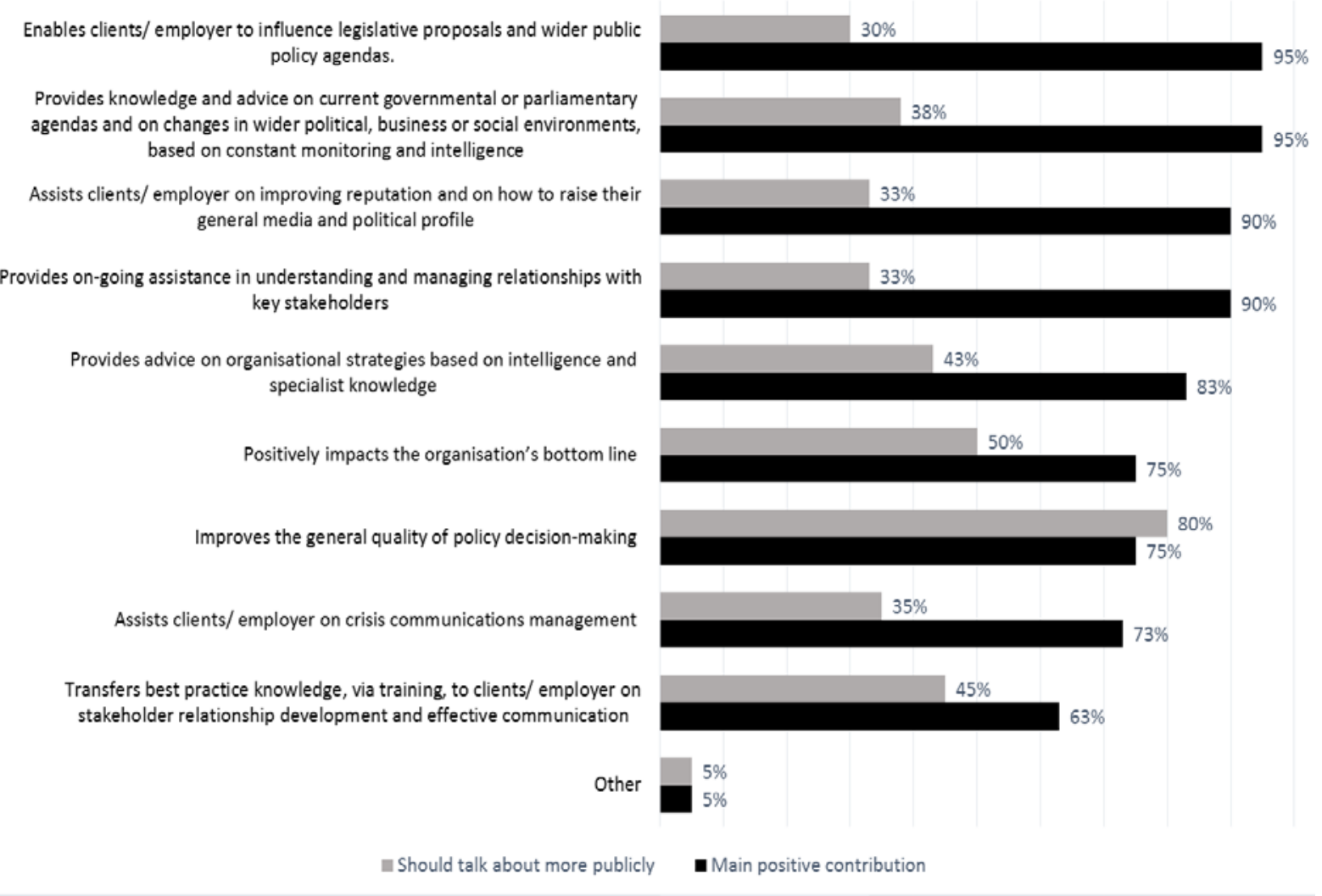

The contribution of public affairs and lobbying practitioners to wider society

When asked in the second round of the Delphi about the themes that had emerged from the first round on the contributions of practitioners to wider society, the highest level of consensus was found for a theme that had also emerged on the questions in regard to practitioner contribution to their employer/clients. The highest level of consensus (see Table V, $88 \%$ ) was found for the theme that practitioners make a positive contribution to society by improving the quality of legislation, regulation and policy-making. Practitioners had also agreed (75\%) that this was an important contribution to the benefit of their employer/clients. While practitioners who responded had a clear orientation to using their skills and knowledge to enable their employer/clients to influence policy and debate, they also believed that the net impact of their activities were also of benefit to wider society through the improvement of the processes of policy-making.

The other theme which appeared in responses to both set of questions in relation to positive contributions to employer/clients or wider society were clustered around a theme concerning knowledge transfers. There was agreement, although the weakest cluster of agreement at $63 \%$, that practitioners contribute to their employer/clients by transferring knowledge in regard to best practice in communication and the development of stakeholder relationships. While $75 \%$ of practitioners agreed that the transfer of knowledge on understanding the functions of government and politics back to their employer/clients could also be categorised as a wider social benefit. This appears logical if democratic politics are accepted as requiring processes whereby groups represent 
and advocate for their interests, and where deliberation and consultation are important functions, then for this process to be coherent groups and social partners are required to make pro-active contributions, which in turn require certain levels of knowledge and competence. There was also agreement, although again one of the weakest $(63 \%)$ within this theme, that the public affairs and lobbying activities of practitioners provided a mechanism by which knowledge of policy issues would be transferred to the public, which in turn would assist in improving the quality of public deliberation.

The next three strongest areas of reveal a self-perception of public affairs practice as being embedded in civic society. There was strong agreement (83\%) that practitioners contributed by providing a working connection and dialogue between politics and wider society. This theme is closely linked to the agreement (75\%) that practitioners also facilitate the participation of their employer/clients, and other community groups, in politics and government, and that this process may contribute to achieving some level of equity of voices that are heard in debates. Likewise, there was agreement (75\%) that public affairs and lobbying practice benefited society through its ability to provide checks and balances on the legislative power of governments. As such, within this theme we see some articulation of why the mobilisation of influence on policy might be accepted as a legitimate democratic role.

Finally, participants in the Delphi were also asked which of the suggested themes should also be talked about more publicly. The areas of strongest consensus in terms of contribution to employer/clients were not the themes which attracted the highest levels of support for being talked about more publicly. Respondents were most keen for there to be more publicity for their work in improving the quality of decision making $(80 \%)$ and how they assist organisations achieve their bottom line objectives (50\%). There was less support for more publicity in regard to their expert knowledge or their ability to influence public agendas on behalf of their employer/clients. A possible explanation is that the respondents' answers had been contextualised by their knowledge of public disquiet in terms of lobbying influence, so that they did not select the functions where there was most consensus, but rather the functions which appeared to be more easily understood as having wider social legitimacy. Likewise, there were also strong levels of support for publicity which would highlight practitioner roles in connecting politics to wider society $(70 \%)$ or facilitating the representation of civic voices in governmental forums (65\%).

\section{Table V: Responses to question:}

Now please consider each of these options below in turn. First, please say whether each is something you recognise as being a main positive contribution of public affairs and lobbying to wider society. Then, please indicate whether it would benefit the public affairs industry to talk more publicly about this contribution (assuming it could be proven). If you don't believe either point applies then select 'Neither'.

Base: Wave1 99 practitioners, Wave 240 PA practitioners, March 2013 


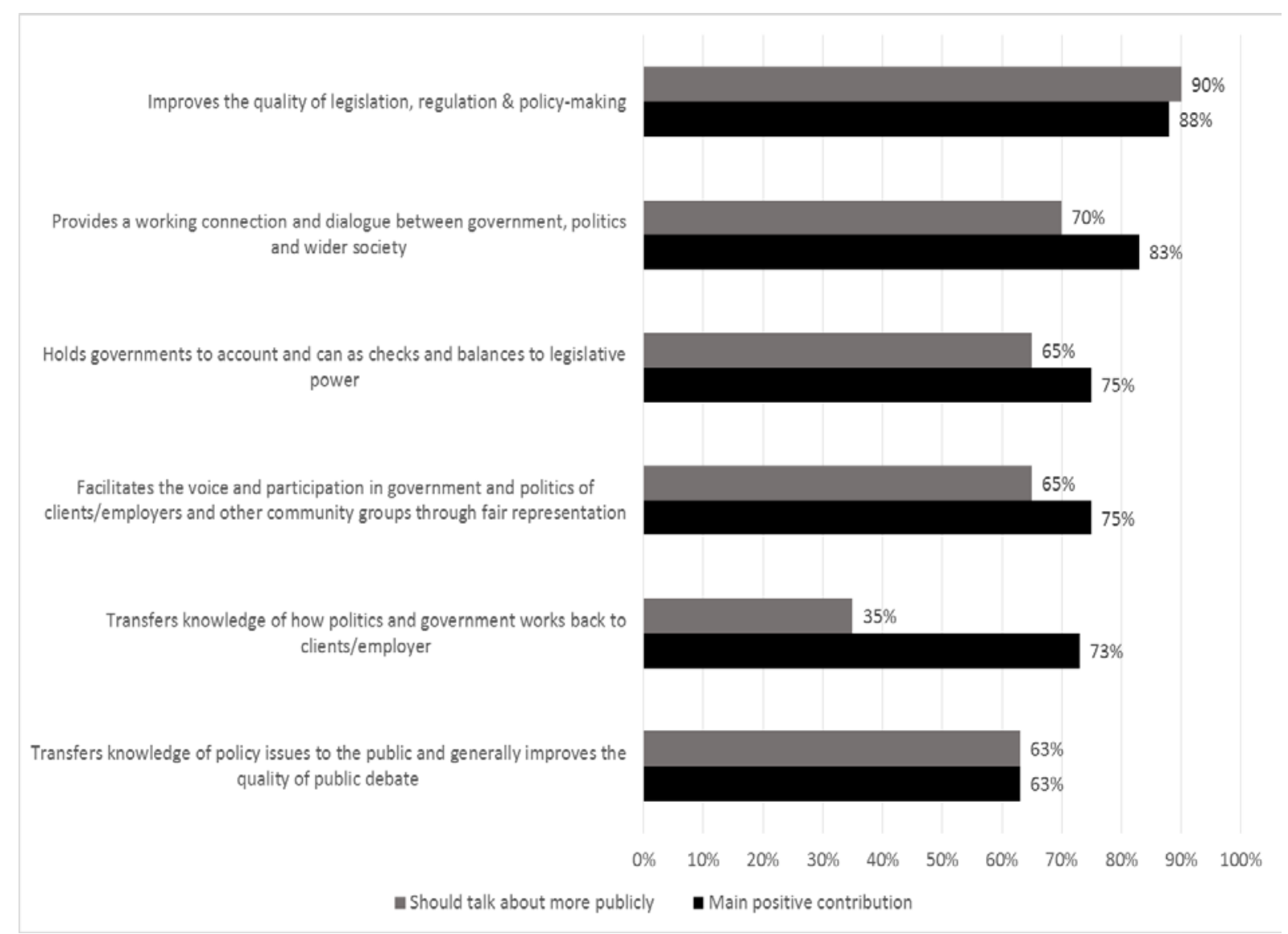

Evaluating the value of public affairs and lobbying to wider society

Respondents to the Delphi's second round were also asked if they agreed with six research evaluation methods for evaluating contributions to wider society that had been identified from responses to the first round. Respondents clearly found it much harder to suggest evaluation methods. There was a higher number of non-responses, which in turn may indicate that the collection of data for this purpose is not a regular activity in public affairs practice. The strongest levels of support (73\%) were found for in-depth case studies that would track how public affairs inputs had influenced the progress of a particular item of legislation. There was also support (65\%) for complementary surveys that tracked the attitudes toward lobbying from the public, politicians and other stakeholders, as well as surveys (60\%) that would report back on lobbying impacts from the perspective of the client. There was support (73\%) for incorporating "bottom line" metrics on impacts on business, the economy and culture. Methods to ascertain if practitioners had been able to increase levels of civic participation in public dialogue had a weaker level of support (55\%), and fewer than half (43\%) agreed that some form of monitoring amendments to bills and policies would constitute a valid method.

\section{How do Public Affairs Practitioners Explain Their Negative Image?}


As part of the first round of the Delphi Survey practitioners were also asked to submit their own explanations of why some people hold negative views towards their activities. In total, 76 of the respondents in the first round provided answers to this open-ended question: In your view, what do you think are the reasons why some people hold negative views regarding the activities of public affairs and lobbying practitioners? The text of these responses were thematically analysed through a process of reading, coding and re-reading. The analysis was oriented toward exploring the practitioners' own interpretations of the factors which influence their public image and reputation.

The main themes (see Table VI.) in the responses coalesced around a view that the functions and practices of lobbyists were widely misunderstood, that while ethical problems existed these were largely due to scandals involving a small minority of practitioners who were frequently felt not to be lobbyists by profession in the first place. The other major themes were located around an awareness that practitioners were primarily perceived as providing unfair advantages and influence for powerful, usually corporate, interests, and a sense that a wider crisis of public trust in politics equally applies to those who are seen as holding a close relationship with political elites.

The main theme was the functions and practices of lobbyists are misunderstood. This theme was coded in 30 of the 76 responses. Within this theme some respondents merely asserted a lack of public knowledge on the functions and practices of lobbyists but without offering any explanations of why this might be. A small number of respondents attributed misunderstandings to a historical legacy of older scandals that had left a lasting impression in the public's mind (Respondent 23 '...failure to shake off the "old boys" image of yesteryear'), particularly the 'cash for questions' scandal that started in 1994 and concerned several sitting members of the UK parliament accepting cash payments in order to undertake lobbying work.

A larger proportion of 25 respondents attributed some role to media portrayals. A majority of those who attributed the media a role in fostering misconceptions also expressed sentiments that suggest many practitioners believe their media portrayals to be in some way inaccurate or unfair. While there was some appreciation that news values would guide media organisations' reporting, sentiment was expressed that this came at the expense of balance or providing a deeper understanding of lobbying practice, a good example is the comment by Respondent 35 that 'the media...rarely cover news of the important and often essential work carried out by lobbyists'. Notable was a sense of grievance present in the responses that much of the negative media coverage which contributed to the perceived misconceptions of lobbying practice was attributed to stories which had been incorrectly branded as lobbying scandals. For example, Respondent 48 'TV programmes that don't reflect reality and scandals that don't involve professional lobbyists'. These sentiments linked closely with another sub-theme from the responses where some practitioners suggested that negative views in regard to their activities are closely bound up with a wider public distrust or disillusionment with party politics, as was observed by Respondent 27 'politicians themselves are often seeing as warping democracy, so anyone seen to making a living from politics is similarly tainted'. The tone of media coverage and the associated anti-politics mood apparent in public opinion was identified by some as contributing to unrealistic assumptions on the nature of influence in public affairs practice, the notion that knowing important people was a prime determinant of 
lobbying success or the overstating of the importance of solitary meetings with civil servants or politicians, in an industry where hundreds of such meetings take place every working day, as one respondent commented 'my favourite is (the newspaper story which says) "the company and its lobbyist had a private meeting with...".

Weaknesses in the regulation of lobbying and particularly the principle of transparency was identified as a theme present in 22 of the responses. The absence of transparency within this theme was identified as contributing to both misunderstandings and to distrust of lobbyists. The process of transparency as defined by Moser (2001:3) is "to open up the working procedures not immediately visible to those not directly involved in order to demonstrate the good working of an institution". As such it is generally regarded as a determinant of good governance that supports the objectives of enhanced democratic accountability and legitimacy. In this theme respondents notably drew upon an imagery of improper brokerage and deal-making, such as a sense that the location of lobbying interactions took place in backrooms or smoke-filled rooms, with influential interactions occurring in unscrutinised spaces involving below the line influence, to possibly advance hidden agendas. Within the responses practitioners were not suggesting this was the actuality of practice, but rather the lack of transparency, the invisibility of much lobbying practice, led to large gaps between how practitioners understand their working practices and how they are perceived by the public and in the media.

Finally, 23 of the responses suggested negative public views towards public affairs practice as being attributable to a perception that lobbying provides unfair advantages and influence for the already powerful. The responses within this theme typically couched the association with elite or corporate power as a wider perception, rather than a critique which they themselves were endorsing. It was perceived as problematic that lobbying was largely associated with larger companies who could afford to deploy public affairs strategies in order to exert disproportionate influence. Here was a sense that practitioners were party to a system that was unfairly rigged in favour of those with financial resources, but also that the consequence of this was lobbying was a tool to advance selfish, financially motivated interests, even where these might clash with wider civic interests or otherwise undermine sensible legislative proposals. This theme was encapsulated by the comment from Respondent 73 that 'often lobbyists are seen as only representing commercial interests and those who have big budgets so their influence is seen to drown out the voices of those with less wealth and power.'

The explanations put forward by the public affairs practitioners who responded to this question revealed perceptions that the industry's negative image was in some senses influenced by the unethical behaviour of people who were members of the political elite, or wanted to influence that elite, but who were not practicing lobbying professionals. The lack of transparency, the wider public mood of anti-politics and the sense that lobbying is perceived to primarily serve the interests of corporate and other elite groups led some respondents to consider that the role of lobbyists could be portrayed as being illegitimate. Respondent 17 stated that lobbyists 'rarely appear to make the political process work' and Respondent 74 considered that attempts to influence were 'considered 
bad'. This led some of the respondents to note or argue that industry or professional bodies needed to be more pro-active in explaining the functions, contributions and working practices of lobbyists.

Table VI: Themes and example quotations based on analysis of 76 open ended responses by public affairs practitioners to the question: In your view, what do you think are the reasons why some people hold negative views regarding the activities of public affairs and lobbying practitioners?

\begin{tabular}{|c|c|}
\hline Theme & Example quotations $R=$ ID number for respondent \\
\hline $\begin{array}{l}\text { Practitioner believe their } \\
\text { functions and practices are } \\
\text { poorly understood }\end{array}$ & $\begin{array}{l}\text { R14: misunderstanding of what we do } \\
\text { R34: lack of awareness about the majority of those active in the field operate } \\
\text { R35: people do not understand what lobbyists do }\end{array}$ \\
\hline $\begin{array}{l}\text { Perceptions are influenced } \\
\text { by memories of scandals } \\
\text { from previous decades }\end{array}$ & $\begin{array}{l}\text { R23: ...failure to shake off the "old boys" image of yesteryear } \\
\text { R59: People think back to "cash for questions" in the 90s and assume that lobbying is based on } \\
\text { financial reward, so there is an outdated perception which has not vanished }\end{array}$ \\
\hline $\begin{array}{l}\text { Media coverage or } \\
\text { portrayals are negative and } \\
\text { contribute to } \\
\text { misunderstandings }\end{array}$ & $\begin{array}{l}\text { R54: Media coverage concentrates naturally on scandals and characters that operate in a way that } \\
\text { captures the public imagination } \\
\text { R35: The media...rarely cover news of the important and often essential work carried out by } \\
\text { lobbyists } \\
\text { R64: reporting of our trade appears quite one dimensional and negative in the mainstream media } \\
\text { R19: The unprofessional conduct of a few...creates a vacuum for the media to fill based on } \\
\text { stereotypes } \\
\text { R48: TV programmes that don't reflect reality and scandals that don't involve professional lobbyists } \\
\text { R41: recent scandals have involved MPs or others rather than lobbyists themselves }\end{array}$ \\
\hline $\begin{array}{l}\text { Negativity towards lobbyists } \\
\text { is part of a wider anti- } \\
\text { politics sentiment }\end{array}$ & $\begin{array}{l}\text { R27: The public's lingering anti-political sentiment also extends to the wider political class - } \\
\text { politicians themselves are often seeing as warping democracy, so anyone seen to making a living } \\
\text { from politics is similarly tainted } \\
\text { R26: people don't trust MPs, so of course they don't trust an industry targeting them } \\
\text { R20: wider antipathy towards anything connected with politics } \\
\text { R66: politics and policy-making is complex and not easily accessible or understood - which creates } \\
\text { distrust }\end{array}$ \\
\hline $\begin{array}{l}\text { Unethical practice does take } \\
\text { place, but is often the } \\
\text { results of the actions of } \\
\text { protagonists who are not } \\
\text { professional lobbyists }\end{array}$ & $\begin{array}{l}\text { R53: much of the industry... will work for anyone and anything if the pay enough } \\
\text { R66: I think that there is a lot of bad lobbying - and it doesn't necessarily influence decisions, but it } \\
\text { does create a bad perception } \\
\text { R20: the image of being able to buy influence is not helped by some claims in agency pitches } \\
\text { R45: former minsters are using their contacts for access } \\
\text { R18: Acts of people who are not in fact lobbyists but simply crooks }\end{array}$ \\
\hline $\begin{array}{l}\text { A lack of transparency and } \\
\text { inadequate regulation } \\
\text { enables a climate of public } \\
\text { distrust }\end{array}$ & $\begin{array}{l}\text { R42: belief that lobbying equals back room deals between those who are personal friends } \\
\text { R3: non-accountability and hidden agendas. Associations that are funded by an organisation or } \\
\text { company must be clear that this is so, otherwise it looks like there is an ulterior motive } \\
\text { R59: there is a lack of transparency e.g. no public register of lobbying so there is a sense that it is } \\
\text { furtive and secretive } \\
\text { R2: The image...of...deals being made in smoke filled rooms } \\
\text { R12: ...UK's lobbying reporting/regulatory system is so inadequate...harmful to the reputation of } \\
\text { public affairs professionals and damages the trust between citizens, their government and the } \\
\text { companies/organisations that lobby the government }\end{array}$ \\
\hline $\begin{array}{l}\text { Lobbying is perceived as } \\
\text { facilitating unfair } \\
\text { advantages and influence } \\
\text { for corporations and other } \\
\text { powerful groups. }\end{array}$ & $\begin{array}{l}\text { R13: A belief among some in society that the system is unfairly rigged in favour of big businesses } \\
\text { and rich individuals } \\
\text { R68: Big Business having access to public affairs support that the person in the street doesn't have } \\
\text { (at least that's the perception) } \\
\text { R73: Often lobbyists are seen as only representing commercial interests and as those who have big } \\
\text { budgets so their influence is seen to drown out the voices of those with less wealth and power } \\
\text { R54: because larger companies can afford bigger and better PA strategies and this gives the } \\
\text { impression of influence being bought }\end{array}$ \\
\hline $\begin{array}{l}\text { Industry bodies, } \\
\text { professional associations } \\
\text { and practitioners }\end{array}$ & $\begin{array}{l}\text { R19: the industry's ineffectiveness at informing the public about what we do and why it's important } \\
\text { R16: We are not very good at explaining publicly what we do } \\
\text { R1: Lobbying desperately needs to PR itself more effectively }\end{array}$ \\
\hline
\end{tabular}


themselves have not done enough to explain the public value of their work
R49: We do not do enough as an industry to defend or protect our reputation. There is a fundamental misunderstanding about what we do, how we operate and what lobbying can deliver. More of us should speak up and be proud about the contributions and outcomes that lobbying has produced

\section{Discussion and Conclusion}

The results of the Delphi survey indicated that when asked to define their functional roles the consensus amongst the sampled practitioners matched closely the major themes found within the public affairs management literature (Table VII). As with surveys undertaken by Beurer-Zuellig et.al., (2009) practitioners agreed that public affairs was a communications-oriented management function. They broadly see themselves as managing and advising organisations on their interactions with the socio-political world, incorporating both the desire to influence that world, but to also to an extent ensuring its concerns become integrated into the workings of senior management, in doing so they demonstrated less ambiguity and stronger common understandings of their roles and functions than might have been the case in previous periods as identified by McGrath et.al. (2010). There is certainly a relevance in these themes to the classic Chase-Jones model (Chase 1984) of issues management, involving a permanent process of issue identification, issue analysis, consideration of strategic options and the development of a programme of action. The danger in this approach is that public affairs success might be measured in terms of pacifying public debates on issues in order to defend vested interests, placing it in disharmony with deliberative theories of democracy. As Heath and Waymer argue (2011) issues management will serve society when it understands its role in supporting the public square, ensuring multiple voices are heard, and arguments put into open critical scrutiny.

\begin{tabular}{|l|l|}
\hline $\begin{array}{l}\text { Table VII. Summary of the Delphi } \\
\text { survey's agreed areas of public affairs }\end{array}$ & - Provision and transfer of specialist knowledge \\
and lobbying practice that contribute & - The scanning and interpretation of external \\
positively to the employer or clients & - environments \\
& $\begin{array}{l}\text { - Monitoring of legislation and legislators } \\
\text { - Strategic management advice }\end{array}$ \\
& $\begin{array}{l}\text { - Building capacity to influence policy } \\
\text { - Management of relationships with stakeholders } \\
\text { - Building media profile }\end{array}$ \\
& $\begin{array}{l}\text { - Contribution to advancing "bottom line" } \\
\text { objectives }\end{array}$ \\
\hline
\end{tabular}

The summary of their agreed areas of contribution to their employer/clients already suggests that practitioners explicitly work on the assumption that legitimacy underpins good relationships and the ability to exert influence. As with Meznar and Nigh (1995) much of the communication management function performed by practitioners is oriented towards maintaining or building external legitimacy. This may involve the traditional concerns with maintaining credibility in terms of being accepted as representing a particular constituency or community of shared interests, but also increasingly 
extends to legitimacy through constructing a permission to be heard by policy-makers built by making credible contributions to civic life.

When practitioners in the Delphi survey were asked to consider their potential contribution to civic society, the level of shared consensus was not as strong as the consensus in regard to their contributions to their employer/clients. In Table VIII. we see the practitioners were able to come to a consensus that their contributions to wider society oriented around their activities which create links and bridges between the workings of government and politics and their employers/clients. This connection of social groups to politics frequently involves the creation of spaces where issues can be debated, but also a process of advocating and explaining the interests of groups in deliberative spaces created by legislators themselves. Yet, the management, or co-creation, of deliberative engagements and how they might be evaluated rarely features prominently in PR teaching (Pieczka 2011), and presents an obvious priority for future research.

\begin{tabular}{|c|c|}
\hline $\begin{array}{l}\text { Table VIII. Summary of the Delphi } \\
\text { survey's agreed areas of public affairs } \\
\text { and lobbying practice that contribute } \\
\text { positively to wider society }\end{array}$ & $\begin{array}{l}\text { - Improving the quality of the policy-making } \\
\text { - } \text { process } \\
\text { - Ennecting society to politicians } \\
\text { - } \text { serve } \\
\text { - } \text { Practitioners as initiators/facilitators of dialogue } \\
\text { - } \text { pobbying provides checks and balances on the } \\
\text { - Educators who transfer knowledge to clients }\end{array}$ \\
\hline
\end{tabular}

In regard to the practitioners sampled in this research there appears to be an emerging conceptualisation of public affairs and lobbying practice as tentatively interpreting its contribution to wider society through making contributions to the building of social capital. As noted earlier it can be argued that public affairs campaigns create social capital by the manner in which they encourage the participation of citizens who are affected by particular issues and by the way constantly changing configurations of civic society organisations communicate and co-operate with each other in the hope of influencing policy-makers. This is a framework which offers distinct possibilities for future research projects to test this claim. The development of research that audits and explores the range of groups who are actively lobbying on issues, the variations in their characteristics and the volume of civic actions that they have been able to mobilise will all assist in understanding if social capital is a valid framework for developing notions of the civic contributions of public affairs practice. Trust will remain a key variable and it will be important to build an understanding of what forms of public affairs and lobbying practice build social capital and encourage further and deeper levels of participation, and what forms might further undermine levels of trust or the belief in the efficacy of engagement. The participation legacy of mobilisation, and the use of ladders of engagement in many advocacy campaigns, is arguably under theorised or critiqued within public affairs scholarship.

While there tend to be low levels of trust in public affairs and lobbying practitioners, it is important that this is not decontextualized. We are living in a period that is characterised by an overall trend of declining trust in social and political institutions, within which we should now currently expect public 
ambivalence or outright distrust in regard to all actors active in the political environment. For example, surveys in the UK found that the majority of the public did not trust any of the major actors in the energy sector. Politicians, energy companies, journalists and the statutory regulator were all distrusted by a clear majority, and even consumer interest groups could only manage to generate equal levels of trust/distrust (Rowe 2014). In relation to public affairs, a process of benchmarking would assist in tracking how its practitioners are regarded in comparison to other actors and professions active in political environments. Surveys and interviews with the public and elite policymaking stakeholders would also allow some longitudinal insight into how any attempts at lobbying reform, or efforts by industry and trade bodies to provide information or develop relationships with the public, might impact on perception, in the understanding that no profession associated with politics and government will - for the foreseeable future - be expected to generate wide levels of public support and endorsement. In a similar vein, the apparent value in understanding that public affairs practitioners can improve the quality of the policy making process through a combination of their information subsidy and ability to scrutinise and challenge proposals emanating from central government, can be tested and benchmarked through a series of quantitative and qualitative interviews with policy stakeholders, particularly those charged with the responsibility of drafting or piloting new regulations or laws through legislatures.

Underpinning much of the public mood of distrust of politics generally, and more specifically, the contribution of lobbyists to public life, is that either governance systems or the work of public affairs practitioners is in some way biased towards the interests of corporate and other elites. While it is impossible to imagine a system of government that does not in some degree reflect hegemonic relationships or ideologies, the challenge is to ensure the system allows all groups to advocate for their interests or values and even challenge existing structures of decision making. If we further accept that no policy settlement can be fully rational or inclusive, there will always be some groups who will disagree or believe their interests are not best served, then we recognise that public affairs and lobbying are frequently competitive pursuits that will culminate in outcomes where some will have been perceived to have won, and others will have lost. Therefore, it becomes vital for democratic legitimacy, and for public trust, that reasonable observers would believe that the process, the rules of the game, are fair and open. We can see the ongoing relevance of Moloney's (2006) call for exploring ways of intervening in the communicative economy to either subsidise or transfer resources to groups in society - who are profoundly impacted upon by legislation and policy - but historically have not had sufficient resources to effectively provide their own information subsidy or mobilisation of affected citizens. Here lies a potential role for more experimental studies that could test interventions to increase the capacity of resource poor groups and evaluate their impacts in terms of influence, the quality of the decision making process and the inclusiveness of participation in the issue discourse. This is also where transparency is important both as a principle, but also as an enabler of research to determine to what degree public affairs and lobbying is a process that enables the empowerment of a highly diverse range of social interests, or whether lobbying influence is skewed towards elite and corporate interests. In many areas there is currently insufficient data. Multi-client agencies are frequently assumed to be enablers of corporate influence, yet there has been no research to establish the median client, in terms of their size and resources. Structurally, some critical realism is required on the assumptions used by both those who accept 
pure liberal pluralism and those who directly equate economic wealth to political influence. Here, the way in which neopluralism, and its contingent approach to influence (Lowery and Gray 2004), has been used in the field of interest group studies holds utility. While a growing plurality of groups do indeed deploy public affairs campaigns, this competition does not automatically produce equal levels of influence or equitable policy outcomes (Godwin et. al 2012), but as discussed earlier, neither is there conclusive proof that resource rich lobbying campaigns will inevitably win policy battles (Baumgartner et.al 2009).

There is a permanent process of evaluating systems of governance and implementing reforms to improve democratic accountability. The role of public affairs and lobbying is now clearly identified as being central to many of these debates. Often missing in these discourses is the requirement for public affairs practitioners to establish themselves as public service professionals. As McGrath (2015) notes this field may be considered a well-established occupation, but professional status remains an unlikely prospect if the public continue to regard the functions of its practitioners as being in many ways illegitimate. Fleisher $(2003,2007)$ has usefully catalogued and argued what might constitute the professional competencies and body of knowledge. McGrath (2015) argues the process requires, amongst other things, transparency, effective professional associations, an articulation of a common set of professional norms and values, but to this to do list we would add an integration into the process of critical research on how public affairs should normatively serve democracy and civic society. For interested stakeholders, including practitioners and their representative bodies there is a clear benefit to developing clearer theoretical and practical understandings of how they can contribute in a healthy democracy and assist in closing existing trust deficits, for this process to make genuine progress then clearly it will require long-term programmes of research to critically test and amend these understandings. 


\section{REFERENCES}

Baumgartner, F.R., Berry, J.M., Hojnacki, M., Kimball, D.C. and Leech, B.L. (2009) Lobbying and Policy Change: Who Wins, Who Loses, and Why. Chicago, IL: University of Chicago Press.

Berg, K. T. (2012). The ethics of lobbying: Testing an ethical framework for advocacy in public relations. Journal of Mass Media Ethics, 27(2), 97-114.

Berry, J. (1997). The interest group society (3rd ed.). New York: Longman

Beurer-Zuellig, B., Fieseler, C. and Meckel, M., 2009. A descriptive inquiry into the corporate communication profession in Europe. Public Relations Review, 35(3), pp. 270-279

Boddewyn, J. (2012). Beyond 'The evolving discipline of public affairs. Journal of Public Affairs. 12(1): 98-104

Bouwen, P. (2002). 'Corporate lobbying in the European Union: the logic of access', Journal of European Public Policy 9(3): 365-90.

CCSDE (2013). Non-Party Campaigning Ahead of Election. Report 1 October 2012. Commission on Civil Society and Democratic Engagement

Chari, R,. Hogan, J,. \& Murphy, G. (2010). Regulating Lobbying: A Global Comparison. Manchester University Press: Manchester.

Chase, W. (1984). Issue management: Origins of the future. Stamford CT: Issue Action Publishers.

CIPR (2013). Definition of Lobbying. Available at http://www.cipr.co.uk/content/policy-

resources/policy/lobbying-regulation/definition-lobbying. Accessed March 2014.

Coombs, WT and Holladay, S. (2007). It's Not Just PR: Public Relations in Society. Malden, MA:

Blackwell.

Curtis, P. (2010). MPs' links to lobbyists a concern, says anti-spin group. 3 June. The Guardian. Available online: http://www.theguardian.com/politics/2010/jun/03/mps-links-lobbyists-spin

Davidson, S. (2014). Everywhere and Nowhere: Theorising and researching public affairs and lobbying within public relations scholarship. Public Relations Review. DOI: 10.1016/j.pubrev.2014.02.023. Available online 24 March 2014

de Lange, R., \& Linders, P. (2006). Public affairs as reality construction: an established paradigm with new implications. Journal of Public Affairs, 6(2), 131-146.

Dinan, W., \& Miller, D. (2007). Thinker, faker, spinner, spy: Corporate PR and the assault on democracy. Pluto Press.

Duff, O. Singleton, D. (2011). Join Clegg's 'leaders' club' - for $£ 25,000$ annual fee. The Independent 18 April. Available online: http://www.independent.co.uk/news/uk/politics/join-cleggs-leaders-club-ndash-for16325000-annual-fee-2269225.html

Fleisher, C. (2003) The development of competencies in international public affairs. Journal of Public Affairs3(1): 76-82

Fleisher, C. (2007) Developing the public affairs body of knowledge. Journal of Public Affairs 7(3): 281-290.

Fleisher, C. C. (2012). Anniversary retrospective, perspective and prospective of corporate public affairs: moving from the 2000+ PA Model toward Public Affairs 2.0. Journal of public affairs, 12 
(1), 4-11.

Gallup (2011). Record 64\% Rate Honesty, Ethics of Members of Congress Low. December 2011 available at: http://www.gallup.com/poll/151460/Record-Rate-Honesty-Ethics-Members-Congress-Low.aspx

Gandy, O. H. (1992). Public relations and public policy: The structuration of dominance in the information age. In E. L. Toth \& R. L. Heath (Eds.), Rhetorical and critical approaches to public relations (pp. 131-164). Hillsdale, NJ: Lawrence Erlbaum Associates, Inc

Gilens, M., \& Page, B. I. (2014). Testing theories of American politics: Elites, interest groups, and average citizens. Perspectives on Politics. Volume 12. Issue 03. September 2014, pp 564 - 581

Godwin, R. K., Ainsworth, S., \& Godwin, E. K. (2012). Lobbying and Policymaking. CQ Press.

Gornall, J. (2014). Under the Influence. British Medical Journal. BMJ 2014;348:f7646

Gray, V. and Lowery, D. (2000). The population ecology of interest representation: Lobbying communities in the American states. University of Michigan Press.

Grunig, L. A., Grunig, J. E., and Dozier, D. M. (2002). Excellent Public Relations and Effective Organizations: A Study of Communication Management in Three Countries. Mahwah, NJ: Lawrence Erlbaum Associates.

Hall, R, \& Deardorff, A (2006). Lobbying as legislative subsidy. American Political Science Review, 100(1), 6984.

Harris, P., \& Moss, D. (2001). In search of public affairs: A function in search of an identity. Journal of Public Affairs, 1(2), 102-110.

Hawkins, T. (2013). The Government's response to Mercer - the wrong solution to a different problem. Statement on PRCA website by Tom Hawkins, policy manager. Accessed September 2013. http://www.prca.org.uk/\%5CThe\%20GovernmentsresponsetoMercer

Heath, R. (1997) Strategic Issues Management: Organizations and Public Policy Challenges. Thousand Oaks, CA: Sage

Heath, R.. (2001). A rhetorical enactment rationale for public relations: The good organization communicating well. In R. L. Heath (Ed.), Handbook of public relations (pp.31-50). Thousand Oaks, CA: Sage

Heath, R., \& Waymer, D. (2011). Corporate Issues Management and Political Public Relations. In J. Strömbäck \& S. Kiousis (Eds.), Political Public Relations and Applications (pp. 138-176). New York: Routledge.

Hickman. L. Ball, J. \& Syal. R. (2012). Questions over climate change minster's links to his adviser. The Guardian 11 September. Available online: http://www.theguardian.com/politics/2012/sep/11/climate-change-ministerlinks-adviser

Horten, M. (2013). A Copyright Masquerade: How corporate lobbying threatens online freedoms. Zed Books: London.

Jordan, G. and Maloney, W. (2007). Democracy and Interest Groups: Enhancing Participation?, London: Palgrave.

Kennedy, H. (2004). Enhancing Delphi research: Methods and results. Journal of Advanced Nursing. 45(5), 504-511 
Kimball, D. C., Baumgartner, F. R., Berry, J. M., Hojnacki, M., \& Leech, B. L. (2012). Who cares about the lobbying agenda. Interest groups \& Advocacy, 1(1), 5-25.

Koeppl, P. (2001). The Acceptance, Relevance and Dominance of Lobbying the EU Commission - A First-Time Survey of the EU Commission's Civil Servants. Journal of Public Affairs, 1: 69-80

L'Etang, J. (2004), Public Relations in Britain: A History of Professional Practice in the 20th

Century, Lawrence Erlbaum Associates, Mahwah, NJ

Larsson, L. (2007). Public trust in the PR industry and its actors. Journal of Communication Management, 11(3), 222-234.

Lowery, D., \& Gray, V. (2004). A neopluralist perspective on research on organized interests. Political Research Quarterly, 57(1), 164-175.

Luoma-aho, V. (2009). On Putnam: Bowling Together--Applying Putnam's theories of community and social capital to public relation. In $\varnothing$. Ihlen, B. van Ruler \& M. Fredriksson (Eds.), Public relations and social theory: Key figures and concepts (pp. 231-251). New York: Routledge.

Miller, D., \& Harkins, C. (2010). Corporate strategy, corporate capture: food and alcohol industry lobbying and public health. Critical Social Policy, 30(4), 564-589.

Meznar M. Nigh D. (1995). Buffer or bridge? Environmental and organizational determinants of public affairs activities in American firms. Academy of Management Journal 38(4): 975-996.

McGrath, C. (2007). Framing lobbying messages: defining and communicating political issues persuasively. Journal of Public Affairs, 7(3), 269-280.

McGrath, C. Harris, P. (2008). The Creation of the US Lobbying Industry. In D. W. Johnson. (Ed.), Routledge handbook of political management (pp. 407-419)

McGrath, C., Moss, D., \& Harris, P. (2010). The evolving discipline of public affairs. Journal of Public Affairs, 10(4), 335-352.

McGrath, C. (2011). Lobbying in Ireland: a reform agenda. Journal of Public Affairs, 11(2), 127-134

McGrath, C. (2015). Learning to Lobby. Interest Groups \& Advocacy 4, 1-6; doi:10.1057/iga.2014.22

Milbrath, L. (1963). The Washington Lobbyists. Chicago: Rand McNally.

Moloney, K. (2006). Rethinking public relations: PR propaganda and democracy. Routledge.

Moser, C. (2001). How Open Is “Open as Possible”? Three Different Approaches to Transparency and Openness in Regulating Access to EU Documents. Political Science Series no. 80, Institute for Advanced Studies.

Newman, M. Wright, O. (2011). Caught on camera: top lobbyists boasting how they influence the PM. 6 December, The Independent. Available online: http://www.independent.co.uk/news/uk/politics/caught-oncamera-top-lobbyists-boasting-how-they-influence-the-pm-6272760.html

OECD. (2009). Lobbyists, Government and Public Trust: Promoting Integrity by Self-Regulation. Paris: OECD, October, GOV/PGC(2009)9

OECD. (2012). Lobbyists, Governments and Public Trust, Volume 2: Promoting Integrity through Selfregulation, OECD Publishing.

Parvin, P.(2007). Friend or Foe: Lobbying in British Democracy. Hansard Society. 2007. http://bit.ly/f8eTOL 
Pieczka, M. (2011). Public relations as dialogic expertise?. Journal of Communication Management, 15(2), 108124.

Pierce, J, Steger, M, Steel, B and Lovrich, N. (1992). Citizens, Political Communication, and Interest Groups: Environmental Organizations in Canada and the United States. Praeger: Westport.

Putnam, R. D. (1995). Bowling alone: America's declining social capital. Journal of Democracy, 6, 65-78.

Renfro, W. (1993). Issues management in strategic planning. Westport, CT: Quorum Books

Rowe, O. (2014). The reputation of the household energy market. Chapter Four in Energy, Politics and the Consumer. Report published by You Gov Plc/Cambridge Programme. April 2014.

http://cambridge.yougov.com/events/energy-politics-and-consumer/

Smith, M.A. (2000) American Business and Political Power: Public Opinion, Elections, and Democracy. Chicago, IL: University of Chicago Press.

Schlozman, K. (2010) Who sings in the heavenly chorus? The shape of the organized interest system. In: L.S. Maisel \& J.M. Berry (eds.), The Oxford Handbook of American Political Parties and Interest Groups. New York: Oxford University Press, pp. 425-450.

Schlozman, K.L., Verba, S. and Brady, H.E. (2012) Unequal Advocacy: Political Voice and the Promise of American Democracy. Princeton, NJ: Princeton University Press

Scott, J. C. (2013). Social Processes in Lobbyist Agenda Development: A Longitudinal Network Analysis of Interest Groups and Legislation. Policy Studies Journal, 41(4), 609-636. doi:10.1111/psj.12034

Smith, M. (2000) American Business and Political Power: Public Opinion, Elections, and Democracy. Chicago, IL: University of Chicago Press.

Sommerfeldt, E.(2013). The civility of social capital: Public relations in the public sphere, civil society, and democracy, Public Relations Review, Volume 39, Issue 4, November 2013, Pages 280-289

Somerville, I. (2011). Managing public affairs and lobbying: persuasive communication in the policy sphere. Chapter Seven in Moss, D \& DeSanto, B (eds) : Public Relations: A Managerial Perspective. Sage, pp. 167-193

Stratton, A. (2011). Liam Fox Resigns. 14 October, The Guardian. Available online: http://www.theguardian.com/politics/2011/oct/14/liam-fox-resigns?

Taylor, M. (2009). Civil society as a rhetorical public relations process. In Heath, R \& Waymer, D. (Eds), Rhetorical and critical approaches to public relations II, Lawrence Erlbaum Associates, Hillsdale, NJ, pp. 76-91)

Turk, J. V. (1985). Information subsidies and influence. Public Relations Review, 11(3), 10-25.

Tusinski Berg, K. (2009). Finding connections between lobbying, public relations and advocacy. Public Relations Journal, 3(3), 1-19.

Valentini, C,. Kruckeberg, D,. \& Starck, K. (2012). Public relations and community: A persistent covenant. Public Relations Review. Volume 38, Issue 5, Pages 873-879

Verčič, D., Van Ruler, B., Bütschi, G., \& Flodin, B. (2001). On the definition of public relations: A European view. Public Relations Review, 27(4), 373-387.

Verčič, A., Verčič, D., \& Sriramesh, K. (2012). Internal communication: Definition, parameters, and the future. Public relations review, 38(2), 223-230. 
Watson, T., \& Wakefield, R. (2014). Delphi 2.0: A reappraisal of Delphi method for public relations research. Public Relations Review. Volume 40, Issue 3, September 2014, Pages 577-584

Watt, H. (2013). Patrick Mercer MP signed a contract with a bogus lobbying company, undercover photographs show. The Telegraph 31 May. Available online:

http://www.telegraph.co.uk/news/politics/conservative/10091781/Patrick-Mercer-MP-signed-a-contractwith-a-bogus-lobbying-company-undercover-photographs-show.html

White, J. \& Blamphin, J. (1994). Priorities for research into public relations practice in the United Kingdom. London: City University Business School/Rapier Research.

Yang, A, \& Taylor, M (2013). The relationship between the professionalization of public relations, societal social capital and democracy: Evidence from a cross-national study. Public Relations Review, Volume 39, Issue 4, November 2013, Pages 257-270

YouGov/Sunday Times 2012. Survey results available at:

http://d25d2506sfb94s.cloudfront.net/cumulus_uploads/document/ic8lcj9svf/YG-Archives-Pol-ST-results\%20\%20121019.pdf

Zoch, L.M. and Molleda, J.C. (2006) 'Building a theoretical model of media relations using framing, information subsidies, and agenda-building', in C. Botan and V. Hazleton (eds.) Public Relations Theory II, Routledge, London, pp. 279-308 